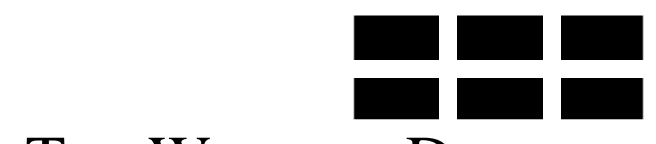

THE WILLIAM DAVIDSON INSTITUTE

AT THE UNIVERSITY OF MICHIGAN BUSINESS SCHOOL

\title{
IMPORTING HIGH-RISK CAPITAL AND REVEALING HIDDEN COMPARATIVE ADVANTAGES
}

\author{
By: Tamir Agmon
}

William Davidson Institute Working Paper Number 724

October 2004 


\section{IMPORTING HIGH-RISK CAPITAL AND REVEALING HIDDEN COMPARATIVE ADVANTAGES}

By

Tamir Agmon*

Graduate School of Business

The College of Management

Rishon Lezion, Israel

April 2004

*Tamir Agmon is the Joel and Erik Stern Professor of Applied Research in Microeconomics and Finance and Dean, Graduate School of Business, The College of Management, Rishon Lezion, Israel 


\section{IMPORTING HIGH-RISK CAPITAL AND REVEALING HIDDEN COMPARATIVE ADVANTAGES}

\section{An Abstract}

The comparative advantage of a country is determined by its factor intensity. In many cases factors of production can be accumulated over time and thus effect a change in the comparative advantage of a given country. The changes in the accumulation of factors can be a policy decision, or it can arise from other economic developments. The change in the comparative advantage of Israel in the last decade of the $20^{\text {th }}$ century where the country has become a center for innovative new technology was affected by the globalization of the US capital market and the ability of Israeli companies and service organization to build an informational infrastructure that has made it possible to import high-risk specific sector capital to Israel. Importing this type of capital has completed the already existing human capital and makes a potential, hidden, advantage into a business reality. The Israeli experience is evidence to the contribution of international capital movements to economic growth of a small country. It also shows the relations between the international finance model of capital movements and the development economics case for the changing pattern of the comparative advantages of small countries, and the contribution of the capital markets to the process.

Keywords: International capital movements, globalization of capital markets, and comparative advantage of small countries.

JEL Codes: F21 


\section{Introduction}

The idea that countries trade according to their comparative advantage is one of the basic propositions of economic theory. However, as it has been demonstrated in the economic literature, (Balassa, 1989), comparative advantage of a given country may and do change in response to accumulation of specific types of physical and human capital.

This paper is motivated first by an empirical observation and second by putting the observation in a context of a model of international economics and finance. The observed phenomenon is the growth of the hi-tech sector in Israel in the period 1995-2000 and the generation of a new comparative advantage for the country. An international finance model of international capital movements makes it possible to understand the process that gives rise to the observed situation, and to gain insights into the contribution of the globalization of the US capital market to growth and development in small countries. In particular, the model demonstrates how the globalization of the US capital market allows for a completion of a potential production function in a specific small country, and thus creating a specific combination of factors that reveals theretofore "hidden”, or implicit comparative advantage in that country. The realization of such an implicit comparative advantage is a substantial force for economic growth.

The growth of the hi-tech sector in Israel in the last decade of the $20^{\text {th }}$ century is demonstrated by the following data: in 1991 the hi-tech sector in Israel raised 58 million dollars as investment through venture capital funds. In 1994 the sector has raised 374 millions dollars, in 1998, 688 millions dollars were raised through venture capital funds. 1,617 millions dollars were raised in 1999, and about 2,500 millions dollars were raised by venture capital funds in 2000.

In 1995 when the Office of the Chief Scientist in the Ministry of Industry and Trade initiated the Israeli venture capital funds industry, there were five funds with about $\$ 10-\$ 20 \mathrm{~m}$. per fund. In 2000 there were 75 active venture capital funds in Israel with typical funding of \$100-\$200 m. per fund. 
In 1991 there were very few start-up companies, (even the term was unfamiliar in Israel), and there were less than 50 technology sector companies beyond the start-up phase, many of them related to the defense industry. By 2000 there were about 2,500 start-up companies in Israel, and about 250 technology sector companies beyond the start-up phase, most of them not related to the defense industry, with a substantial proportion of sales and activities outside Israel.

In 1993 there were four new public offerings, (IPOs), by ventures backed Israeli companies in NASDAQ. The four companies have raised together a little more than 100 million dollars. In the period 1994-2000 there were more then 130 IPOs and secondary offerings by Israeli firms in the US and in Europe. More than \$5,500 m. were raised. At the same time major US companies like Texas Instruments, Intel, Applied Materials, Lucent, Johnson \& Johnson, and others acquired more than 30 Israeli hi-tec companies, (the most famous was the acquisition of an Israeli start-up company Chromatis by Lucent for a $\$ 4.0$ billion in Lucent’s shares).

The Israeli Bureau of Statistics estimates that in 2000 more than 50\% of the annual growth, $3.5 \%$ out of $6.5 \%$, was originated in the hi-tech sector. This is a substantial proportion much higher than in the US and in other developed countries.

In this paper it is shown that this extraordinary development was possible due to a cooperative effort between human and financial capital. As Israel does not have, and cannot have sufficient quantities of high risk capital, this type of specific sector capital has to be imported from abroad. The imported specific sector, high risk capital combined with the existing specialized labor created a sufficiently high stock of specialized human and financial capital that creates specific factor intensity that generates new comparative advantage for Israel. The new comparative advantage was expressed by the establishment and the activities of many new firms, most of them start-ups.

It is well documented that countries do generate new comparative advantage by accumulating specific types of capital. In a number of studies Balassa have researched the changing pattern of comparative advantage in manufacturing goods in both developed and developing countries. (For a summary of Balassa studies see his "Comparative Advantage Trade Policy and Economic 
Development”, 1989). The case of Israel is different in two aspects; first, it took a combination of sector specific capital and specialized human capital to generate the new comparative advantage. The second aspect is that the import of sector specific capital requires building a special infrastructure for the transfer of information. As it is shown later, this informational and professional infrastructure played a very important role in the development of the new global dimension of the Israeli economy.

The issue of how Israel has generated and accumulated specialized human capital with technological and entrepreneurial skills is not discussed here. Therefore the discussion focuses on two related processes. The first process describes the contribution of specific sector capital to the generation of a new comparative advantage at the macroeconomic level. A family of new competitive advantages at the firm level expresses the new comparative advantage. The second process deals with the necessary conditions for international trade in high risk capital. The second process is a necessary condition for the first. Hence, the importance of the professional and informational infrastructure that facilitates the international trade in high risk capital.

The rest of the paper is organized in four sections. In section 2 the international finance approach to sector specific capital is discussed. The application of this approach to the issue of creating a new comparative advantage for a given country is presented and discussed. In section 3 of the paper the analysis is extended to the level of the firm using an accounting paradigm. The necessary and sufficient conditions for international trade in high-risk capital are discussed in section 4 . A brief summary is presented in the last section, section 5 


\section{Sector Specific Capital and the International Trade in Securities}

The discussion presented in this section is based on a model of an international capital movement with sector-specific capital, (Wong, 1995, pp. 189-194). The standard macroeconomic equilibrium model is adjusted in two ways; first, a vector of securities corresponding to the different sectors replaces the abstract term sector-specific capital. In the simplest form there is one specific security for each sector. Second, the implications of the model are calibrated in the context of generating a new comparative advantage and the resulting trade in securities. Discussing the model in terms of securities helps to anchor the macroeconomic, abstract model in the reality of the capital market.

Following common presentation it is assumed that the world is comprised of two countries, home and foreign. There are two sectors in the economy of both countries. One sector comprises all current and future consumption of all existing goods and services. The second sector comprises all activities that may yield the consumption of all the yet to be developed goods and services. The two sectors are denoted the "existing" and the "new” sectors respectively. Assume further that the home country is small, and that the foreign country is a large country. The analysis is focused on the home (small) country.

In the home country there are two securities, one representing all the existing economic activities, the "market" security, and one representing future potential consumption, the "future consumption” security. In addition, there is a risk less security that allows individuals to build portfolios of different risk levels.

Following common presentations in finance, the "market" security is fully described by its expected return and standard deviation, $E_{R M}$ and $S_{R M}$. The "future consumption", $F_{C}$, security is fully described by $E_{R F C}$ and $S_{R F C}$.

It is assumed that:

$E_{R F C}>E_{R M}$ and $S_{R F C}>S_{R M}$ 
Issuing of securities raises capital. Assume that there are three groups of issuers of securities:
a. Firms issuing "market" securities
b. Firms issuing "future consumption" securities
c. Individuals and financial intermediaries issuing risk less securities

The following analysis focuses on the two first groups of issuers of securities.

Define the capital raised by issuing "market" securities as general capital, and the capital raised by "future consumption" securities as high-risk specific capital. Assume that the home country has a potential for the production of "new" sector goods and services, but that in order to realize this potential the home country has to import "new" sector-specific capital. This is so because the investors/consumers of the home country wish to hold a much smaller proportion of "future consumption" securities in their portfolio, then the optimal proportion of the production of future goods and services. Therefore firms who wish to issue "future consumption" securities have to do so at the capital market of the large country where the demand for such securities is large enough.

"New" sector goods and services exist only in the form of rights to receive them in the future. That is in a form of securities issued by firms that are spending money now in order to produce these goods and services in the future. In more concrete terms, the import of sector-specific capital from the foreign to the home country is done by a purchase of "future consumption" securities issued by firms in the home country by investors in the foreign country. (In some respects these securities are real options).

In general, given two sectors in each country,

$\bar{K}_{i} \forall i=1,2$ is the available capital of type $\mathrm{i}$ in the home country from its own market.

Let $k_{i}$ be the inflow of foreign capital of type i to the home country from the foreign country. $k_{i}<0$ is an outflow of capital. 
$K_{i}=\bar{K}_{i}+k_{i}$ is the total capital of type i available to the home country from both the local and the foreign markets.

Total payment to the foreign capital is $r_{1} k_{1}+r_{2} k_{2}$, where $\mathrm{r}$ is a function of prices and capital flows, $r_{i}=r_{i}\left(p, k_{1}, k_{2}\right)$. Payments for foreign capital are repatriated to the foreign country. In the abstract model the rental rate is specified as a current payment like interest rate. In the capital market the rental rate is expressed as an expected return. In the case of the rental rate for specific-sector capital for the "new" sector is very likely that the return will be in terms of a price appreciation of the securities in question. The return on almost all the technology securities listed on NASDAQ in the period 1995-2000 was in price appreciation and not in dividend yield.

In the following analysis the new sector is referred to as sector 1 , and the existing sector as sector 2 .

In general it can be shown that:

$r_{1} \cdot p>0$ (If prices in sector 1 rise rental rate in 1 rises)

$r_{2} \cdot p<0$ (If prices in sector 1 raises rental rate in 2 falls).

Where $r_{i} \cdot p$ is the partial derivative of the return to capital in sector $\mathrm{i}$ to the changes of prices in sector 1. As prices are expressed as relative prices, it is sufficient to denote price as p, the relative price of future consumption of new goods and services (new consumption) in terms of existing consumption. As a great simplification, one can argue that the price level of NASDAQ relative to that of the Dow Jones is an approximation for the relative price of new to existing consumption.

The information technology (IT) revolution brought about a rise in prices in sector 1, new consumption. (These are expected prices in the future, as currently the goods and services of sector 1 do not exist). The rise in the prices raises the (expected) rental rate in sector 1 and causes 
an increase in the price of the "future consumption" securities. This was clearly evident in the behavior of NASDAQ in the period 1997-2000.

The price rise in sector 1 creates an incentive for an investment in the infrastructure that enables and supports international trade in "future consumption" securities. (See section 4 below for an extension of this argument).

\subsection{The Formal Model}

The formal model calculates the equilibrium values for capital flows, interest rates, trade flows and prices.

Let the Indirect Trade Utility function, (ITU), be:

$V\left(p, k_{1}, k_{2}\right)$ and $b=-r_{1} \cdot k_{1}-r_{2} \cdot k_{2}$

Where $b$ is the payments to the suppliers of capital

The export function of sector 1 is:

$X_{1}\left(p, k_{1}, k_{2}\right)$

Let $X_{1} \cdot p$ be the partial derivative of $X_{1}$ relative to the change in the relative price p, and $X_{1} \cdot j$ be the partial derivative of $X_{1}$ relative to changes in the flow of foreign capital to the Home country, $k_{j} \forall j=1,2$

In equilibrium the export of extended consumption by the home country is equal to the import of these goods by the foreign country.

Therefore, the following system can be set up:

1. $X_{1}\left(p, k_{1}, k_{2}\right)+X^{*}{ }_{1}\left(p^{*}, k_{1}^{*}, k_{2}{ }_{2}\right)=0$

2. $k_{i}=k_{i}^{*}=0$

3. $p=p^{*}$ In equilibrium 
4. $r_{i}\left(p, k_{1}, k_{2}\right)=r_{i}^{*}\left(p^{*}, k_{1}^{*}, k_{2}^{*}\right)$

Where * denotes the Foreign country.

There are six unknown variables: $p, p^{*}, k_{j}, k_{j}^{*} j=1,2$

But, in equilibrium $p=p^{*}$, and the sum total of the capital flow within a sector is zero. Therefore the system can be solved.

A Graphical Solution: 

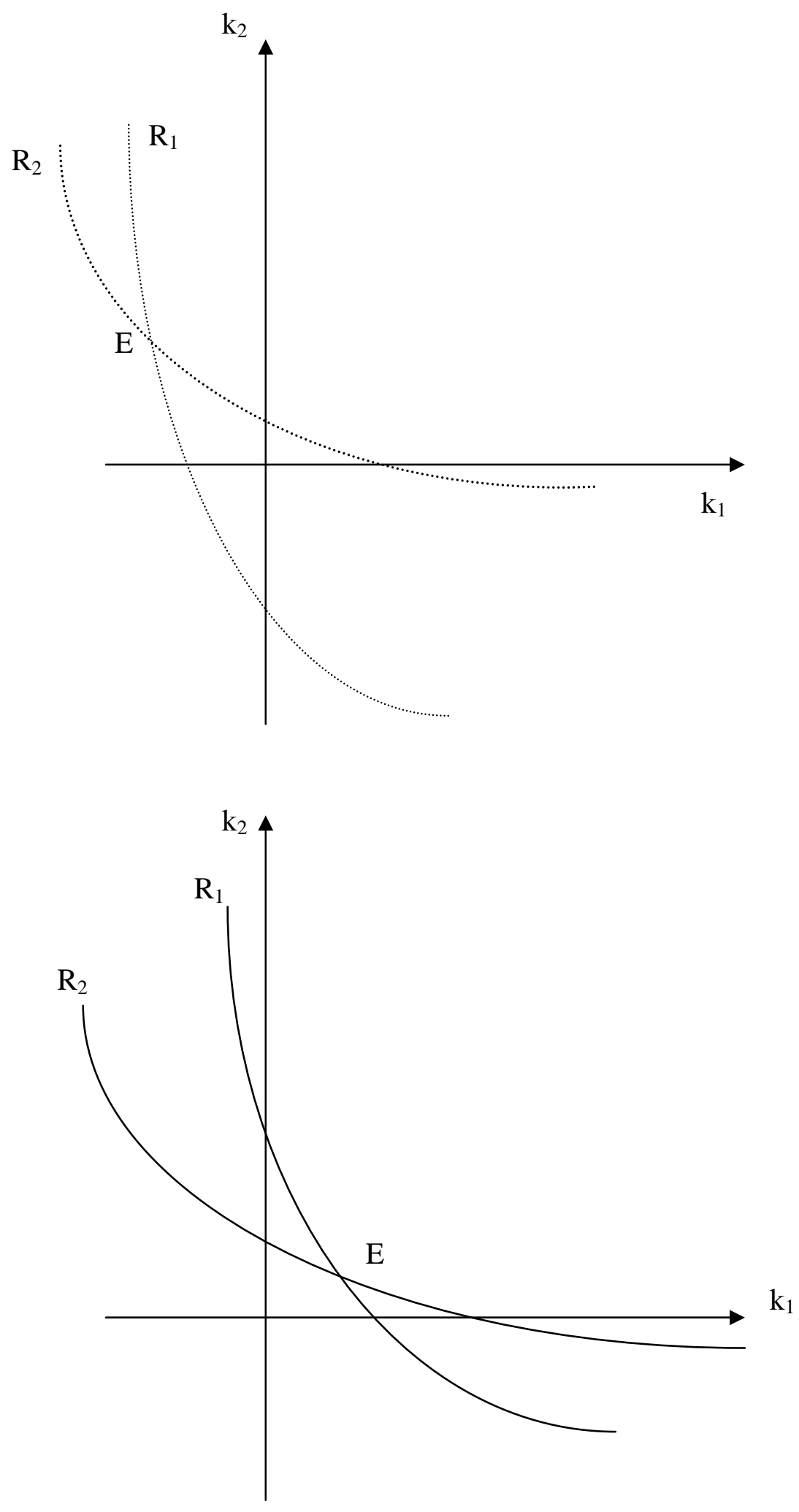
$r_{i}\left(p, k_{1}, k_{2}\right)=r_{i}^{*}\left(p^{*}, k^{*}, k_{2}^{*}\right) \quad i=1,2$

Schedule $R_{i}$ represents the locus of $k_{1}$ and $k_{2}$ that clear the market of extended goods, 1 , and for “market” and "future consumption" securities. In the case that both countries face world price p, the slope of $R_{i}$ is negative.

One interesting outcome of the model is that countries that specialize in high- risk' new consumption activities and their firms sell new consumption securities will import low risk securities. In other words, these countries will import high-risk capital, (sell high-risk securities) and will export general or low risk capital, (buy low risk securities). This is known in the international finance literature as cross hauling, for example see Wong, (1995) pp. 192-193. A specific example of such behavior is the sale of shares of successful Israeli technology companies by their managers/entrepreneurs and their investment in real estate. 


\subsection{Analysis:}

The model can be applied to better understand what has happened in Israel in the last decade of the $20^{\text {th }}$ century, and in particular five years period 1995-2000. As was illustrated in section 1 above, this period was characterized by a tremendous growth of the hi-tech sector.

Using the standard international finance model to discuss this period is useful for a number of reasons. First, It provides a better understanding of what has happened by putting it in the context of a normal economics model. This is important in itself because the popularity of the talk on "new economics" and the great disappointment of the period 2001-2003. It is shown here that what has happened both in the boom and in the decline periods fell within "normal" economic processes. "Future consumption” securities are risky by definition. It is normal for the price of risky securities to exhibit high volatility. Therefore, a period of "boom" and a period of "bust” are all within normal price behavior of such securities. Second, the model emphasizes the important role of the capital market and in particular the ability of firms in one country to import sector specific capital from another country, or in other words of Israeli firm to sell securities in NASDAQ. Third, it directs attention to the need to create the necessary professional and informational infrastructure that will make it possible to trade in high-risk, and other sector specific capital across countries.

\section{Issuing and Selling Securities Representing Future Potential (New) Consumption: A Single Firm Perspective}

A comparative advantage of a country consists of the business activities of many firms. If the international trade in sector-specific capital is a necessary condition to reveal a "hidden" comparative advantage in a country, it should be expressed at the level of the single firm as well. This is done in this section. A model of the firm is presented. It is shown that certain assets depend on the availability of appropriate liabilities. Only if managers and entrepreneurs realize that the necessary type of liabilities (securities) is available for them, they will embark on activities that required this special funding. 
The relation between the real decisions, what to do, and the financial decisions, how to fund the activity is presented through an illustration. Suppose that a group of engineers in the small country is considering two alternatives: (a) to open a machine shop that will produce a stream of revenues with a low expected return and a low risk, or (b) to embark on a new venture to develop a new product with a high expected return and a high risk. Assume further that the first alternative will produce positive cash flows from the first year, while the second alternative, if successful, will produce positive cash flows only five years from its initiation. The expected value, and the risk, of the second alternative are much higher than the first.

The first alternative may produce a stream of income, and consumption, for the entrepreneurs from the beginning, and if it needs financing the engineers (management) may issue a bond to a bank, (borrow money). Other financing may be provided as equity by the engineers themselves or by other investors in return to a share in the profits. The securities issued by the machine shop will be a part of the portfolio of securities held by households (investors) in the small economy.

Selling securities to finance the development of a start-up company, the second alternative, is like writing a real option on yet to be developed new product. Assume that the development period for the new product is five years. At the end of the development period the new technology may or may not be successful. The probability of failure is large, and this is reflected in the risk-expected return structure of the venture. In a small closed economy the allocation of savings by investors for such venture that are real options on human capital to produce "new" sector goods and services is very small. The allocation of the investors puts a limit on the availability of capital for entrepreneurs to finance high-risk ventures. It is likely that in this case most engineers will not even attempt to go the start-up way.

Once the small country is open to international movements of sector-specific capital, the engineers in the small country can avail themselves to high risk capital from the large country. In other words, they can raise funds for their venture outside their home country. Due to the size difference what may be a small transfer of funds from the large country point of view may go a long way in the small country. This is so as a S-small percentage of the combined portfolio of the 
households in the large country may be sufficient to fund many enterprises and to build a new comparative advantage in a small country.

Another way to examine the situation is by comparing the equilibrium in a closed small economy to that in an open economy. It is very likely that in a world of one small and one large country, consumption, investment, and savings decisions of the inhabitants of the small will differ according to the type of the equilibrium solution; a closed small economy, or a open economy.

The identity of savings and investments in equilibrium as expressed in the risk-return relationship in the capital market creates a constraint for entrepreneurs. . The constraint is less binding for entrepreneurs in a small country once there are capital movements. In particular, entrepreneurs in the small country may derive relatively bigger advantage from the opening of the capital market. (This is similar to the situation in the Ricardo model where trade is opened between a large and a small country).

The idea of complimentarity in a production function is not a new one in microeconomics. In the microeconomic literature complimentarity means that given an initial endowment of factors of production in a country a certain comparative advantage can be generated only if the firms in this country have access to a number of additional factors in a given proportion. If not, the firms execute a "second best" production plan. The same principle operates in the capital market, prior to embarking on an investment program management, or the entrepreneurs make sure that their business plan can be financed. If appropriate finance is not available, management turns to a different investment program. In terms of the illustration presented above, in the absence of sufficient high-risk capital the engineers will opt to start a machine shop. The economy will be at full employment, and in equilibrium and the potential new comparative advantage with its potential for additional growth will remain "hidden".

The incentive to make an implicit, "hidden" comparative advantage into an explicit "operational" advantage has to do with the demand for future goods and services and the ability of entrepreneurs in the small country to provide them. The change in the demand creates the 
incentive to import high-risk capital. In order to do that some firms have to invest money and other resources in the building of the informational infrastructure.

The question is what is the process that generates demand to the expected future aggregate consumption of new goods and services that may or may not exist. We do know from observing the boom and the decline in the innovative hi tech sector that the demand for this type of yet to be created goods and services is very volatile. There is no one accepted explanation to this or any other boom periods. Unfortunately, here one can only speculate, and the risk of a tautology looms large.

Wherever the horizon that people see expands there is an increase in the expectations for new and better future. These expectations translate to an increase in the aggregate demand for new goods and services. The new horizon can be geographical, like in the period of the discoverers of new lands, or it may be organizational, like the introduction of the rational production in the US at the three first decades of the $20^{\text {th }}$ century. The Information Technology (IT) revolution is another case of an expanding horizon period. This time around the expansion of the horizon was for most part technological, and has to do with the speed that information in the broadest sense of the term is processed and delivered.

Whenever there has been a horizon-expanding revolution it was associated with new firms, and investment in new products and services. Some turned out to be successful and other have failed. Some new firms have grown up to be the new era major players, many more have failed and where acquired or disappeared.

The new and innovative nature of many of the firms that were seeking financing in the new consumption sector, and their domicile in the small and foreign country from the point of view of the investors in the large country, require the building of a special infrastructure to enable the capital flow of sector specific capital. This aspect is discussed in section 4 below. 


\section{Valuation, Information and Communication: The Role of Financial and Professional Services}

The level of required information and its availability, and the degree of active management required by the investors is directly related to the level of risk of the security. When an investor makes an investment in a risk less government bond all the relevant information is publicly available. Holding a government bond is a passive investment, and the outcome of the investment, the realized holding period return is independent of the efforts of the investors. As was argued by Brennan and Trigeorgis this is the case where "an investment project is completely described by a specified stream of cash flows whose characteristics are given;” (Brennan and Trigeorgis, 2000, pp. 1-2). Investing in a share of stock of a publicly traded company differs in two important aspects. First, although much of the relevant information is public and is sanctioned by regulations, still there is a substantial amount of relevant information that is not available to the public. Second, the investor has the right to appoint directors to represent her in the management of the company. As it has been demonstrated many times such representation and the relations between investors and management in general is a complex issue discussed in the financial economics literature under the heading “agency costs”.

Investing in real options on human capital as it has been described earlier is a much more complex process. First, most of the relevant information is private, innovative and proprietary. The whole point in start-ups companies, and to some degree in more mature high technology firms, is that they posses private information. There is a discussion in the contracting literature that suggests a built-in tension between the entrepreneurs and the investors. This is so as the entrepreneurs feel that their proprietary information is what makes them valuable for the investors, and the investors feel that they need the information to make the appropriate judgment regarding the value of the investment.

Investments like those discussed in this paper are characterized as situations "in which it is assumed that projects can be managed actively to take into account not only the resolution of exogenous uncertainties but also the (re) actions of outside parties”, (Brennan and Trigeorgis, ibid. p.2). The need to continue and manage actively the project after the initial investment 
decision has been made is a major difference between a simple DCF based investment like buying a government bond and investing in a real option in the form of a start-up company. Venture capital funds were established by investors to solve these issues. (For a discussion of these issues see Ravid and Speigel, 1997, and Gompel and Lerner, 2000).

In section 2 above it has been shown that in some cases importing a sector specific, high-risk, capital is a necessary condition for making a potential comparative advantage a reality. In section 3 it has been shown that small countries import high-risk capital by selling securities by companies specializing in producing hi-tech goods and services for the future, (consumption of yet to be developed goods and services). These securities require high level of specific and credible information. A necessary condition for importing a sector specific, high-risk, capital is an informational infrastructure that will make information generated and sent by firms in the small country credible. An informational infrastructure for trade in securities is as necessary as a transportation system is necessary for trade in goods.

Infrastructure systems by their very nature have economy of scale. Often the government initiates them. In Israel the first step in building up an informational infrastructure for the import of high-risk capital was the setting up of the Yozma funds. The Yozma funds were established under law by the Chief Scientist of the Israeli Ministry of Industry and Trade to foster joint efforts by foreign and domestic investment in the high-tech sector. Israeli investors or financial institutions together with a foreign venture capital fund initiated the funds. The Israeli government contributed one third of the capital invested in the fund. The government also agreed to sell its part to the other two partners at the initial cost if the fund will turn to be a success. In this way the government has taken a part of the initial risk by contributing a third of the investment, but it also subsidizes a success.

The most important part of the Yozma funds was that they provide an easy way for US and other international venture capital funds to get acquainted with Israel and with Israeli start-up firms. When the information provided by a small entrepreneurial firm from a small country goes to a large country capital market via a large country financial intermediary like a venture capital fund its credibility is enhanced substantially. Moreover, the initial activity of seeking out 
information from small start-up firms by the Yozma funds was accompanied by creating a network of auditors, lawyers, and investment bankers that together have created a strong informational infrastructure that enable the large volume of high-risk capital imports to Israel from the US. The data provided in section 1 is evidence to the success of this informational infrastructure in the period 1995-2000. The institutional structure of the informational infrastructure requires high initial investment, followed by relatively low maintenance costs. The fact that the initial fixed investment was made at a time of a boom makes it more likely that the infrastructure will survive the decline period. Recent statistics on the growth of high-risk funds raising by Israeli venture capital funds in the first quarter of 2004 suggests that this is indeed the case.

\section{Concluding Remarks}

One of the most important processes that drive the economic growth of nations is the changing pattern of their comparative advantage. The literature of the development economics focuses on the accumulation of physical and human capital as the main explanatory variable for changes in the comparative advantage of developing nations. In this paper the focus is on the contribution of international capital movements to the realization of potential comparative advantage in small nations. Following the neo-classical trade model it is argued that entrepreneurs in small countries may benefit more from the opening of the capital markets and from free movement of specific factor capital then those located in a large country. In this context the role of the import of sector specific capital to Israel in the period $1995-2000$ is explored. The analysis that spans the space

from macroeconomics to finance and international business demonstrates the need for cooperation among the government, foreign financial intermediaries and domestic firms. In the case of Israel the government provides the initial effort in setting up the necessary informational infrastructure. Given the required basic credible information, foreign financial intermediaries helped domestic firms in the selling of high-risk securities. The sale of the securities in the US and the international capital market is what has made the potential comparative advantage of Israel into a reality. 


\section{References}

Balassa, B. - “Comparative Advantage Trade Policy and Economic Development”, New York University Press, NY, 1999

Brennan, M.J., and G. Trigeorgis, ”Project Valuation”, 2000, MIT Press

Helpman E. “A simple Theory of International Trade with Multinational Corporations. “ Journal of Political Economy 92 (no.3), 1984

Ravid, A., and Spiegel Toehold Strategies, Takeover Laws and Rival Bidders : Journal-of-Banking-and-Finance. August 1999; 23(8): 1219-42

Wong, K.Y, “International Trade in Goods and Factor Mobility”, MIT Press 1995 


\section{DAVIDSON INSTITUTE WORKING PAPER SERIES - Most Recent Papers}

The entire Working Paper Series may be downloaded free of charge at: www.wdi.bus.umich.edu

CURRENT AS OF 10/29/2004

\begin{tabular}{|c|c|c|}
\hline Publication & Authors & Date \\
\hline $\begin{array}{l}\text { No. 724: Importing High-Risk Capital and Revealing Hidden } \\
\text { Comparative Advantages }\end{array}$ & Tamir Agmon & Oct. 2004 \\
\hline $\begin{array}{l}\text { No. 723: Which entrepreneurs expect to expand their businesses? } \\
\text { Evidence from survey data in Lithuania }\end{array}$ & $\begin{array}{l}\text { Ruta Aidis and Tomasz } \\
\text { Mickiewicz } \\
\end{array}$ & Oct. 2004 \\
\hline No. 722: Russia from Bust to Boom: Oil, Politics or the Ruble? & $\begin{array}{l}\text { Bruno Merlevede and Koen } \\
\text { Schoors }\end{array}$ & Oct. 2004 \\
\hline No. 721: Distance to the Efficiency Frontier and FDI Spillovers & $\begin{array}{l}\text { Klara Sabirianova Peter, Jan } \\
\text { Svejnar, and Katherine Terrell }\end{array}$ & Sept. 2004 \\
\hline $\begin{array}{l}\text { No. 720: An Analysis of Gender Wage Differentials in Russia from } \\
\text { 1996-2002 }\end{array}$ & Rita Hansberry & Sept. 2004 \\
\hline $\begin{array}{l}\text { No. 719: Returns to Schooling in Russia and Ukraine: } \\
\text { A Semiparametric Approach to Cross-Country Comparative Analysis }\end{array}$ & \begin{tabular}{|l|} 
Klara Sabirianova Peter and \\
Yuriy Gorodnichenko \\
\end{tabular} & Sept 2004 \\
\hline $\begin{array}{l}\text { No. 718: The emergence of large shareholders in mass privatized } \\
\text { firms: Evidence from Poland and the Czech Republic }\end{array}$ & Irena Grosfeld and Iraj Hashi & Aug. 2004 \\
\hline $\begin{array}{l}\text { No. 717: Wage Determination Under Communism and In Transition: } \\
\text { Evidence from Central Europe }\end{array}$ & $\begin{array}{l}\text { Swati Basu, Saul Estrin and Jan } \\
\text { Svejnar }\end{array}$ & Aug. 2004 \\
\hline No. 716: The Evolution of Cross-Region Price Distribution in Russia & Konstantin Gluschenko & July 2004 \\
\hline $\begin{array}{l}\text { No. 715: Languages in the European Union: The Quest for Equality and } \\
\text { its Cost }\end{array}$ & $\begin{array}{l}\text { Jan Fidrmuc and Victor } \\
\text { Ginsburgh } \\
\end{array}$ & July 2004 \\
\hline $\begin{array}{l}\text { No. 714: Voice of the Diaspora: An Analysis of Migrant Voting } \\
\text { Behavior }\end{array}$ & Jan Fidrmuc and Orla Doyle & July 2004 \\
\hline $\begin{array}{l}\text { No. 713: International Coercion, Emulation and Policy Diffusion: } \\
\text { Market-Oriented Infrastructure Reforms, 1977-1999 }\end{array}$ & $\begin{array}{l}\text { Witold J. Henisz and Bennet A. } \\
\text { Zelner and Mauro F. Guillen }\end{array}$ & July 2004 \\
\hline $\begin{array}{l}\text { No. 712: Votes and Vetoes: The Political Determinants of Commercial } \\
\text { Openness }\end{array}$ & $\begin{array}{l}\text { Witold J. Henisz and Edward D. } \\
\text { Mansfield }\end{array}$ & July 2004 \\
\hline $\begin{array}{l}\text { No. 711: Interest Groups, Veto Points and Electricity Infrastructure } \\
\text { Deployment }\end{array}$ & $\begin{array}{l}\text { Witold J. Henisz and Bennet A. } \\
\text { Zelner }\end{array}$ & July 2004 \\
\hline $\begin{array}{l}\text { No. 710: Firms' Price Markups and Returns to Scale in Imperfect } \\
\text { Markets: Bulgaria and Hungary }\end{array}$ & \begin{tabular}{|l|} 
Rumen Dobrinsky, Gábor Körösi, \\
Nikolay Markov, and László \\
Halpern \\
\end{tabular} & July 2004 \\
\hline $\begin{array}{l}\text { No. 709: The Stability and Growth Pact from the Perspective } \\
\text { of the New Member States }\end{array}$ & Gábor Orbán and György Szapáry & July 2004 \\
\hline $\begin{array}{l}\text { No. 708: Contract Violations, Neighborhood Effects, and Wage Arrears } \\
\text { in Russia }\end{array}$ & \begin{tabular}{|l|} 
John S. Earle and Klara \\
Sabirianova Peter \\
\end{tabular} & July 2004 \\
\hline $\begin{array}{l}\text { No. 707: Determinants of Employment Growth at MNEs: Evidence } \\
\text { from Egypt, India, South Africa and Vietnam }\end{array}$ & $\begin{array}{l}\text { Sumon Kumar Bhaumik, Saul } \\
\text { Estrin and Klaus Meyer }\end{array}$ & July 2004 \\
\hline $\begin{array}{l}\text { No. 706: Economic Reform in Tanzania and Vietnam: A Comparative } \\
\text { Commentary }\end{array}$ & $\begin{array}{l}\text { Brian Van Arkadie and Do Duc } \\
\text { Dinh }\end{array}$ & June 2004 \\
\hline $\begin{array}{l}\text { No. 705: Beliefs about Exchange-Rate Stability: Survey Evidence } \\
\text { from the Currency Board in Bulgaria }\end{array}$ & $\begin{array}{l}\text { Neven T. Valev and John A. } \\
\text { Carlson } \\
\end{array}$ & June 2004 \\
\hline No. 704: Returns to Schooling in China Under Planning and Reform & $\begin{array}{l}\text { Belton M. Fleisher and Xiaojun } \\
\text { Wang }\end{array}$ & June 2004 \\
\hline $\begin{array}{l}\text { No. 703: Return to Skills and the Speed of Reforms: Evidence from } \\
\text { Central and Eastern Europe, China and Russia }\end{array}$ & \begin{tabular}{|l} 
Belton M. Fleisher, Klara \\
Sabirianova Peter, and Xiaojun \\
Wang \\
\end{tabular} & June 2004 \\
\hline $\begin{array}{l}\text { No. 702: What Makes Small Firms Grow? Finance, Human Capital, } \\
\text { Technical Assistance, and the Business Environment in Romania }\end{array}$ & $\begin{array}{l}\text { J. David Brown, John S. Earle } \\
\text { and Dana Lup }\end{array}$ & May 2004 \\
\hline $\begin{array}{l}\text { No. 701: The Effects of Multiple Minimum Wages Throughout the } \\
\text { Labor Market }\end{array}$ & $\begin{array}{l}\text { T. H. Gindling and Katherine } \\
\text { Terrell } \\
\end{array}$ & May 2004 \\
\hline No. 700: Minimum Wages, Inequality and Globalization & $\begin{array}{l}\text { T. H. Gindling and Katherine } \\
\text { Terrell }\end{array}$ & May 2004 \\
\hline No. 699: Self-Selection and Earnings During Volatile Transition & Ralitza Dimova and Ira Gang & May 2004 \\
\hline No. 698: Ecology and Violence: The Environmental Dimensions of War & $\begin{array}{l}\text { Timothy L. Fort and Cindy A. } \\
\text { Schipani }\end{array}$ & May 2004 \\
\hline
\end{tabular}

